\title{
IN VITRO ANTIBACTERIAL ACTIVITIES OF MARINE SPONGE-ASSOCIATED BACTERIA AGAINST PATHOGENIC VIBRIO SPP. CAUSES VIBRIOSIS IN SHRIMPS
}

\author{
ARIS TRI WAHYUDI*, JEPRI AGUNG PRIYANTO, DIAN RETNO WULANDARI, RIKA INDRI ASTUTI
}

Division of Microbiology, Department of Biology, Faculty of Mathematics and Natural Sciences, IPB University (Bogor Agricultural

University), Bogor 16680, Indonesia

Email: aristri2011@gmail.com

Received: 07 Jul 2019, Revised and Accepted: 30 Sep 2019

\section{ABSTRACT}

Objective: This study was aimed to isolate and screen marine sponge-associated bacteria producing anti-Vibrio compounds and to identify their compounds from the bacterial extract.

Methods: Sponge-associated bacteria were isolated by spread plate method. Their anti-Vibrio activity against Vibrio parahaemolyticus, V. harveyi, and $V$. vulnificus was determined by dual culture test. Three potential isolates were identified based on $16 \mathrm{~S}-\mathrm{rRNA}$ gene analysis. All isolates producing anti-Vibrio compounds was tested for their haemolytic characters in blood agar medium. Anti-Vibrio activity of the most potential isolate was also tested by using its supernatant, extract, and concentrated culture. Chemical composition of crude extract derived from that isolate was identified by GC-MS analysis.

Results: 68 bacterial isolates have been isolated from the marine sponge, Spongia sp., Svenzea sp., Ircinia sp., and Igernella sp. Of 68 isolates, 15 $(22 \%)$ isolates had anti-Vibrio activities in various spectra against three Vibrio species, including V. harveyi, V. parahaemolyticus, and V. vulnificus. All isolates producing anti-Vibrio compounds were non-haemolytic. Bacterial isolates coded as D6.6, D6.19, and P4.17 have broad spectra. They could inhibit at least two Vibrio species as indicated by the clear zone formed around bacterial colonies. Based on 16S-rRNA, these isolates were closely related (similarity $\geq 99 \%$ ) to Brevibacterium casei strain M Sw oHS, Bacillus altitudinis strain FJAT 47750, and Bacillus altitudinis strain PgBe190, respectively. D6.6 isolate was the most potential isolate, which could inhibit three Vibrio species. Consistently, its anti-Vibrio activity also confirmed by their supernatant, concentrated culture, and crude extract of that isolate. The crude extract derived from this isolate contained 10 major compounds that are biologically active.

Conclusion: This study suggests that 15 bacteria strains isolated from marine sponges were potentially could inhibit Vibrio's growth in vitro. These isolate could be further explored as anti-Vibrio agent.

Keywords: Anti-Vibrio, Bioactive compounds, GC-MS, Sponge-associated bacteria, 16S-rRNA

(C) 2019 The Authors. Published by Innovare Academic Sciences Pvt Ltd. This is an open access article under the CC BY license (http://creativecommons.org/licenses/by/4.0/) DOI: http://dx.doi.org/10.22159/ijpps.2019v11i11.34814

\section{INTRODUCTION}

Infectious diseases in shrimp, particularly Vibriosis have become a serious problem in aquaculture. The disease is caused by pathogenic Vibrio, including $V$. harveyi, $V$. vulnificus, $V$. parahaemolyticus, $V$. alginolyticus, V. anguillarum, and V. splendidus [1]. Even though the use of antibiotics is considered effective for treating Vibriosis, the overuse of those compounds resulted in resistance in some Vibrio species. For example, more than $50 \%$ of Vibrio parahaemolyticus strains isolated from marine and freshwater fish surprisingly presented high resistance to ampicillin (88\%), amikacin (64\%), and kanamycin (50\%) [2]. Consequently, the challenge to find new antibiotics encourages us to look for alternative ways to deal with Vibrio infections mainly in shrimp aquaculture.

The oceans are presently being investigated in the search for new active compounds. There is an increased interest in natural compounds produced by organisms living in marine habitats. Based on the database of marine natural products, more than 32,000 compounds have been identified [3]. Interestingly, nearly $75 \%$ of Indonesia is ocean. This condition provides an endless source for exploration of marine natural products, particularly those from marine bacteria. The water column of the oceans contains approximately $10^{6}$ bacterial cells per milliliter [4]. In addition, they also have an association with the marine organism, especially sponge. The bacterial density could reach $10^{9}$ cells per cm3 of sponge tissue [5], indicating that the possibility to find diverse potential bacteria isolated from sponge tissue is high. Bioactive compounds extracted from these bacteria have some biological activities, including antibacterial [6-8], antioxidant, antiglycation, antiaging [9], anticancer [10-12], antiviral, and antifungal [13].
Taking into account those potential characters, the investigation of sponge-associated bacteria in producing anti-Vibrio compounds needs to be done.

In some previous studies, sponge-associated bacteria isolated from Indonesian Sea showed potent anti-Vibrio activities. Nearly 12 $(15 \%)$ of bacterial strains isolated from sponge markedly exhibited anti-Vibrio properties in various spectra [14]. Supporting that studies, marine bacteria isolated from North Java Sea also have antibacterial activity against pathogenic Escherichia coli [15]. Based on those reports, marine bacteria isolated from sponge was explored for the discovery of new anti-Vibrio compounds. This study was aimed to isolate and screen anti-Vibrio activities of spongeassociated bacteria. We also report the identity of the most potential bacterial isolate based on 16S-rRNA analysis.

\section{MATERIALS AND METHODS}

\section{Sponge and Vibrio spp}

Spongia sp., Svenzea sp., Ircinia sp., and Igernella sp. were collected from Pramuka Island, Thousand Island, Jakarta. Vibrio harveyi P-275 (collection of Research and Development Center of Brackish Water Aquaculture, Maros, Indonesia), Vibrio vulnificus 195B, and Vibrio parahaemolyticus ATCC 17802 (collection of The Standard of Fish Quarantine, Quality Qontrol and Fishery Product Safety, Jakarta, Indonesia) were used for primary screening targets.

\section{Isolation of sponge-associated bacteria}

Nearly $1 \mathrm{~g}$ of each sponge biomass was washed by using sterile seawater. It was then macerated and diluted through several dilution serials (from $10^{-1}$ to $10^{-4}$ ). About $100 \mu \mathrm{l}$ of each dilution was 
plated on seawater complete (SWC) agar medium ( $5 \mathrm{~g}$ peptone, 1 yeast extract, $3 \mathrm{ml}$ glycerol, $750 \mathrm{ml}$ seawater, $250 \mathrm{ml}$ distilled water), Zobel marine agar (ZMA), and nutrient agar medium by using spread plate technique. The inoculated plates were incubated at $\pm 28^{\circ} \mathrm{C}$ for $24 \mathrm{~h}$. The growing colonies were then characterized and purified on Luria Bertani agar $(1 \mathrm{~g}$ tryptone, $1 \mathrm{~g} \mathrm{NaCl}, 0.5 \mathrm{~g}$ yeast extract, 1.5 agar, $100 \mathrm{ml}$ distilled water).

\section{Screening for anti-Vibrio activity from sponge-associated bacteria}

Antibacterial activity of sponge-associated bacteria was tested by using the dual culture method. Each Vibrio strain was cultured in SWC broth medium for $24 \mathrm{~h}$. About $1 \%(\mathrm{v} / \mathrm{v})$ was then inoculated to the melted SWC agar medium, and homogenized. The inoculated medium was then poured into the sterilized plate. After the medium was solid, each sponge-associated bacterial isolate was streaked on that medium and incubated at $\pm 28{ }^{\circ} \mathrm{C}$ for $24 \mathrm{~h}$. Antibacterial activity was indicated by the formation of a clear zone around the bacterial colonies.

\section{Haemolytic assay}

The potential isolates producing anti-Vibrio compounds were tested for their haemolysis ability using a blood agar medium. The bacterial isolates were streaked on that medium and incubated for $24 \mathrm{~h}$ at $\pm 27^{\circ} \mathrm{C}$. The formation of clear zones around the bacterial colonies indicates that the isolate is haemolytic positive.

\section{Identification of the potential bacteria}

The potential bacterial isolates were cultured on SWC medium, incubated at $28^{\circ} \mathrm{C}$ and agitated in $120 \mathrm{rpm}$ overnight. About $3 \mathrm{ml}$ of bacterial culture was transferred into a sterile microtube and centrifuged at $10.000 \mathrm{rpm}$ for $10 \mathrm{~min}$. The genomic DNA was extracted using the Genomic DNA Mini Kit (Blood/Cultured Cell, Geneaid, Taiwan). The procedures were carried out according to the manufacturer's instructions. The 16S-rRNA gene was amplified using $1387 \mathrm{R}$ primer (5'-GGG CGG WGT GTA CAA GGC-3') and 63F primer (5'-CAG GCC TAA CAC ATG CAA GTC-3') [16] with a targeted fragment of $1300 \mathrm{bp}$. The PCR reaction was performed under the following conditions: $25 \mu \mathrm{l}$ of GoTaq Green Mastermix 2x (Promega, Madison, USA), $5 \mu \mathrm{l}$ of $1387 \mathrm{R}(10 \mathrm{pmol}), 5 \mu \mathrm{l}$ of $63 \mathrm{~F}$ primers $(10$ pmol), $2 \mu \mathrm{l}$ DNA template $(\sim 100 \mathrm{ng} / \mu \mathrm{l})$, and adjusted with nucleasefree water (NFW) to $50 \mu$ l. The cycling conditions (30 cycles) were pre-denaturation $94{ }^{\circ} \mathrm{C}$ for $5 \mathrm{~min}$, denaturation $94{ }^{\circ} \mathrm{C}$ for $30 \mathrm{~s}$, annealing $55^{\circ} \mathrm{C}$ for $45 \mathrm{~s}$, elongation $72{ }^{\circ} \mathrm{C}$ for $1 \mathrm{~min} 30 \mathrm{~s}$, and postPCR $4^{\circ} \mathrm{C}$ for $5 \mathrm{~min}$. The PCR products were sequenced in FirstBase, Malaysia. The sequences were compared to the other 16S-rRNA sequences in GenBank NCBI database (http://ncbi.nlm.nih.gov) using BlastN (Basic Local Alignment Search Tool). The phylogenetic tree was constructed in molecular evolutionary genetics analysis program (MEGA) version 7.0 using the neighbor-joining method.

\section{In vitro anti-Vibrio assay of the most potential isolate}

The most potential isolate was tested to confirm its anti-Vibrio activity. The isolate was cultured in SWC broth medium for $72 \mathrm{~h}$, and incubated at room temperature $\left( \pm 27^{\circ} \mathrm{C}\right)$. After incubation, nearly 1.5 $\mathrm{ml}$ of that suspension was centrifuged in $10.000 \mathrm{rpm}$ for $5 \mathrm{~min}$. The supernatants and pellets were separated into different eppendorf. The pellets were added with $150 \mu \mathrm{l}$ of supernatants so that the suspension contained ten times of cell number. About $20 \mu \mathrm{l}$ of that culture was inoculated onto the SWC agar medium containing the bacterial tests. In addition, nearly $20 \mu \mathrm{l}$ of supernatants were also inoculated on that medium and the plates were incubated for $24 \mathrm{~h}$ at $\pm 27^{\circ} \mathrm{C}$. About $1 \mathrm{l}$ culture was also used for the extraction of its bioactive compounds. Then, bacterial cultures were added with ethyl acetate solvent in ratio $1: 1(\mathrm{v} / \mathrm{v})$ and shaken continuously for $20 \mathrm{~min}$. The bacterial culture and the ethyl acetate layers were separated. The solvent layer was then evaporated using rotary evaporator at $50 \mathrm{oC}$. The extract was then stored at $4^{\circ} \mathrm{C}$. This extract was tested for its anti-Vibrio activity in a concentration of $5000 \mathrm{ppm}$. DMSO and ampicillin (100 ppm) were served as the negative and positive control, respectively.

\section{Chemical identification of the bacterial extract}

The extract derived from the most potential bacteria attributed to broad spectrum of anti-Vibrio activity was identified by using the GC-MS technique. The GC-MS analysis was carried out in an Agilent Technologies $6890 \mathrm{~N}$ inert C, USA equipped with a fused capillary column $(58 \times 0.25 \mu \mathrm{m}$ ID $\times 0.25 \mu \mathrm{m}$ df $)$. For GC-MS identification, an electron ionization system was executed in electron impact mode with ionization energy of $70 \mathrm{eV}$. Helium gas $(99.999 \%)$ was used as a carrier gas at a constant flow rate of $1 \mathrm{ml} / \mathrm{min}$, and $1 \mu \mathrm{l}$ of suspension was injected (a split ratio of 50:1). The temperature of injector was maintained at $280^{\circ} \mathrm{C}$. The ion-source temperature was $200^{\circ} \mathrm{C}$, and the oven temperature was operated from $110{ }^{\circ} \mathrm{C}$ (isothermal for 2 min), with an increase of $10^{\circ} \mathrm{C} / \mathrm{min}$ to $280^{\circ} \mathrm{C}$, then $5^{\circ} \mathrm{C} / \mathrm{min}$ to 280 ${ }^{\circ} \mathrm{C}$, ended with a $20 \mathrm{~min}$ isothermal at $280^{\circ} \mathrm{C}$. Mass spectra were taken at $70 \mathrm{eV}$, a scan-interval of $0.5 \mathrm{~s}$ and fragments from 45 to 450 Da. The solvent delay was 0 to $2 \mathrm{~min}$, and the total GC-MS running time was $47 \mathrm{~min}$. MSD ChemStation Data Analysis software (G1701EA E.02.02.1431) was used for mass spectra and chromatograms analysis.

\section{RESULTS}

\section{Bacterial isolates from sponge}

From 4 sponge species used, each sponge showed a different number of bacteria. As isolated by using three different medium (SWC, ZMA, and NA), the total number of bacterial isolates from each sponge was found to be diverse. These isolates were selected by their colony morphology (shape, color, texture, optical characters, and size). Seventeen bacterial isolates, 19 isolates, 16 isolates, and 15 isolates were isolated from Spongia sp., Svenzea sp. Ircinia sp., and Igernella sp., respectively. In instance, a total of 68 bacterial isolates were obtained from four sponges.

\section{Anti-Vibrio activities of sponge-associated bacteria}

Of 68 bacterial isolates, 15 isolates (22\%) markedly exhibited antibacterial activity against three Vibrio species in various spectra (table 1). These isolates were able to inhibit at least one Vibrio species. Interestingly, the isolate coded as D6.6 (isolated from Spongia sp.) showed a broad spectrum of anti-Vibrio activity. This isolate was able to inhibit all three Vibrio species, including $V$. harveyi, $V$. parahaemolyticus, and $V$. vulnificus. The other bacterial isolates displayed narrow spectra of anti-Vibrio activities. They displayed antibacterial activity only in one or two test strains of Vibrio.

\section{Haemolytic character of te selected isolates}

In the present study, 15 potential isolates showed a negative haemolysis reaction. These isolates were not able to lyse red blood cells in the medium, indicating that the bacteria were suspected not to be pathogenic to human and animal. In this study we used $V$. vulnificus as positive control. There was a lytic zone around the $V$. vulnificus's colony.

\section{The molecular identification bacterial isolates}

Three potential isolate coded as D6.6, D6.19, and P4.17 were selected for molecular identification. The 16S-rRNA gene amplification of these isolates showed DNA fragment $\sim 1300 \mathrm{bp}$ in size. Based on BlastN program, both D6.19 and P4.17 isolate were highly homolog (similarity $94 \%$ and $99 \%$ ) with Bacillus altitudinis in different strains, and D6.6 was similar to Brevibacterium casei (similarity 100\%), as shown in table 2. Consistently, D6.19 and P4.17 were located in the Bacillus clade, while D6.19 was located in the Brevibacterium clade (fig. 1).

The anti-Vibrio activity of extract, supernatant, and concentrated culture of the most potential isolate

The supernatant concentrated culture, and extract from D6.6 isolate consistently exhibited clear zone formation (fig. 2). The best inhibition of Vibrio's growth was showed by the concentrated culture against $V$. vulnificus. Ampicillin as a positive control also showed anti-Vibrio activity at $100 \mathrm{ppm}$, while there was no clear zone formation in DMSO treatment. 
Table 1: Inhibition of Vibrio's growth by sponge-associated bacteria

\begin{tabular}{|c|c|c|c|c|}
\hline \multirow[t]{2}{*}{ Sponges } & \multirow[t]{2}{*}{ Isolate code } & \multicolumn{3}{|c|}{ Anti-Vibrio activity ${ }^{*}$} \\
\hline & & V. harfeyi & V.parahaemolyticus & V. vulnificus \\
\hline \multirow{3}{*}{ Spongia sp. } & D6.3 & - & +++ & - \\
\hline & D6.6 & + & + & + \\
\hline & D6.9 & + & + & - \\
\hline \multirow{7}{*}{ Svenzea sp. } & D6.8 & + & - & - \\
\hline & D6.18 & + & ++ & - \\
\hline & D6.19 & ++ & +++ & - \\
\hline & $\mathrm{P} 4.11$ & + & ++ & - \\
\hline & P4.17 & - & +++ & + \\
\hline & P4.19 & - & - & + \\
\hline & $\mathrm{P} 4.21$ & ++ & - & - \\
\hline \multirow{4}{*}{$\begin{array}{l}\text { Ircinia sp. } \\
\text { Igernella sp. }\end{array}$} & P5.10 & + & - & - \\
\hline & P5.20 & + & + & - \\
\hline & P6.13 & - & ++ & - \\
\hline & P6.15 & - & ++ & - \\
\hline
\end{tabular}

*Clear Zone diameter: 0 mm: -; 0.1-2.5 mm: +;>2.5-5 mm: ++;>5 mm: +++

Table 2: The identity of bacterial isolates based on the 16S-rRNA sequence

\begin{tabular}{|c|c|c|c|c|c|}
\hline Isolates code & Closest relative strain & E-value & Identity & Query cover & Accession number \\
\hline D6.6 & Brevibacterium casei strain M Sw Ohs & 0.0 & 94 & 100 & KF777366 \\
\hline D6.19 & Bacillus altitudinis strain FJAT 47750 & 0.0 & 99 & 100 & MG651154 \\
\hline P4.17 & Bacillus altitudinis strain PgBe190 & 0.0 & 100 & 100 & MH211281 \\
\hline
\end{tabular}

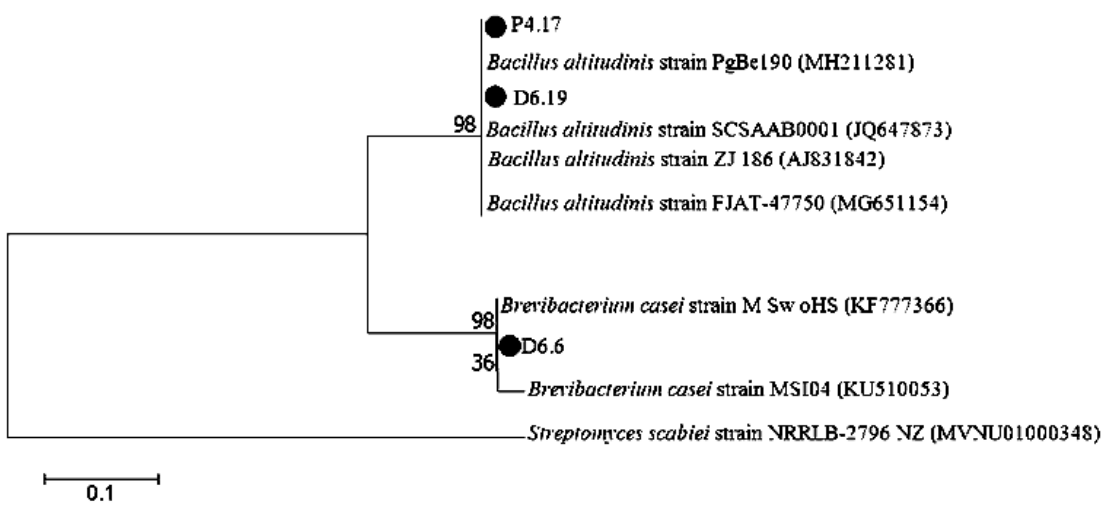

Fig. 1: Genetic relationships of three potential isolates compared to their closest relative strains

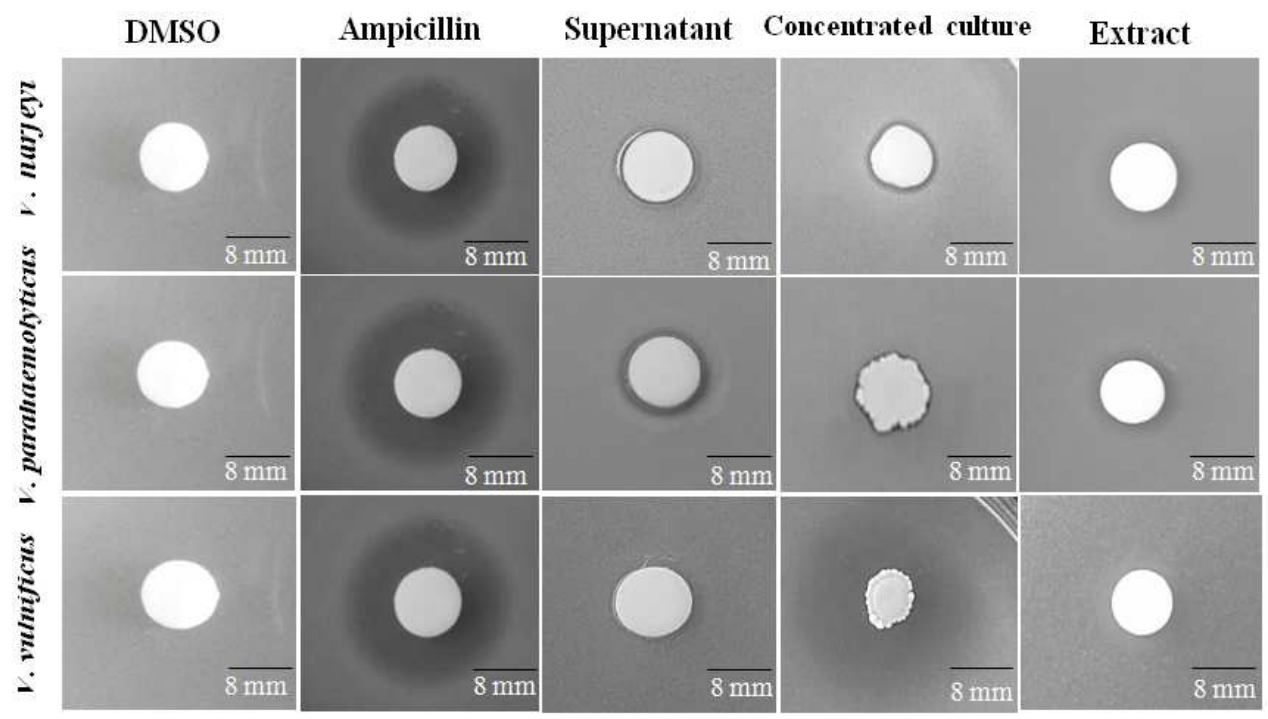

Fig. 2: Anti-Vibrio activities of supernatant, concentrated culture, and crude extracts of D6.6 isolate in SWC agar medium after $24 \mathrm{~h}$ incubation at $\pm 27^{\circ} \mathrm{C}$ 


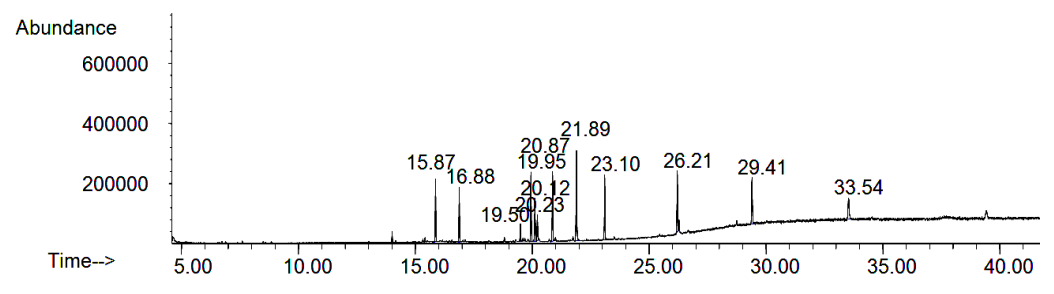

Fig. 3: GC-MS chromatogram of a crude extract derived from D6.6 isolate

Table 3: Ten major compounds in the crude extract derived from D6.6 isolate

\begin{tabular}{|c|c|c|c|c|c|c|}
\hline No. & Compounds & Formula & $\begin{array}{l}\text { Retention } \\
\text { time }\end{array}$ & Peak area $(\%)$ & $\begin{array}{l}\text { Similarity } \\
(\%)\end{array}$ & Biological activity [references] \\
\hline 1. & Thiophene,2-butyl- & $\mathrm{C}_{10} \mathrm{H}_{16} \mathrm{~S}$ & 15.87 & 8.18 & 53 & Anticancer, antiinflammation [17] \\
\hline 2. & Octadecane & $\mathrm{C}_{18} \mathrm{H}_{38}$ & 16.88 & 6.90 & 98 & Unknown \\
\hline 3. & Silane, trimethyl-2-propyne- & $\mathrm{C}_{6} \mathrm{H}_{12} \mathrm{Si}$ & 19.50 & 3.20 & 38 & Unknown \\
\hline 4. & Eicosane & $\mathrm{C}_{20} \mathrm{H}_{42} \mathrm{O}$ & 19.95 & 9.33 & 97 & Antifungal [18] \\
\hline 5. & $\begin{array}{l}2(5 \mathrm{H}) \text {-furanone, } 5 \text {-(2-methyl-2- } \\
\text { propenyl)-4-methyl- }\end{array}$ & $\mathrm{C}_{9} \mathrm{H}_{12} \mathrm{O}_{2}$ & 20.12 & 6.61 & 97 & Unknown \\
\hline 6. & $\begin{array}{l}\text { Cyclohexane,1-(cyclohexylmethyl)- } \\
2 \text {-methyl, cis- }\end{array}$ & $\mathrm{C}_{14} \mathrm{H}_{26}$ & 20.22 & 4.89 & 47 & Unknown \\
\hline 7. & Heptane,1,7-dibromo- & $\mathrm{C}_{7} \mathrm{H}_{14} \mathrm{Br}_{2}$ & 20.87 & 10.08 & 43 & Unknown \\
\hline 8. & Fluoranthene & $\mathrm{C}_{16} \mathrm{H}_{10}$ & 21.89 & 15.20 & 97 & Enzyme inhibitor [19] \\
\hline 9. & Docosane & $\mathrm{C}_{22} \mathrm{H}_{46}$ & 23.10 & 9.87 & 97 & Antibacterial [20] \\
\hline 10. & Tetracosane & $\mathrm{C}_{24} \mathrm{H}_{50}$ & 26.21 & 11.91 & 97 & Cytotoxic [21] \\
\hline
\end{tabular}

\section{Chemical composition of the crude extract from D6.6 isolate}

Based on GC-MS analysis, D6.6 derived extract was dominated by ten compounds, including thiophene, 2-butyl-; octadecane; silane, trimethyl-2-propyne-; eicosane; 2(5H)-furanone, 5-(2-methyl-2propenyl)-4-methyl-; cyclohexane,1-(cyclohexylmethyl)-2-methyl, cis-; heptane,1,7-dibromo-; fluoranthene; docosane; and tetracosane (table 3). These compounds showed different retention time and peak area (fig. 3).

\section{DISCUSSION}

In this study, we investigated the potential of sponge-associated bacteria as the candidate of antiVibriosis on shrimps. The number of bacteria isolated from 4 sponges species was found to be diverse. All sponges, Spongia sp., Svenzea sp. Ircinia sp., and Igernella sp. containing at least 15 bacterial isolates proved to be sources of diverse bacteria that produced bioactive compounds. The number of bacteria isolated may be influenced by the isolation technique, nutrient content on medium, and type of sponge used. In this study, a total of 68 isolates were obtained. These culturable bacteria could be the microbiological evidence of symbiotic interaction between the sponge and their bacterial symbiont. Of 68 isolates, 15 isolates (22\%) markedly exhibited anti-Vibrio activities in various spectra against $V$. harveyi, V. parahaemolyticus, and $V$. vulnificus, as indicated by the clear zone formation around bacterial colonies. The different spectra of anti-Vibrio activity indicated the chemical diversity of anti-Vibrio bioactive compounds produced by these bacteria. Based on their anti-Vibrio activity, it is likely that these isolates have an important role in supporting host defense mechanisms. According to haemolytic assay, these isolates were haemolytic negative, suggesting that these potential isolates were not pathogenic bacteria in human. Thus, these isolates can potentially be explored as the antiVibriosis agent.

Three isolates coded as D6.6, D6.19, and P4.17, showed great antiVibrio activity. Two isolates, D6.19 and P4.17 were closely related (similarity $\geq 99 \%$ ) to Bacillus altitudinis strain FJAT 47750 and Bacillus altitudinis strain PgBe190, respectively. Surprisingly, D6.6 isolates showed low similarity (94\%) to Brevibacterium casei strain M Sw oHS suggesting the novelty of this isolate. Both Bacillus and Brevibacterium genera were commonly known as the antimicrobial compounds producer. As reported by Gao et al. [22], marine Bacillus strain has a strong anti-Vibrio activity against 29 Vibrio strains. Supporting these results, Abubakar et al. [23] also demonstrated that Bacillus isolates were able to inhibit not only Gram-positive bacteria, but also Gram-negative bacteria, including $V$. harveyi, Staphylococcus aureus, E. coli, and Pseudomonas aeruginosa. Other Bacillus associated with marine sponge in Thousand Island, Indonesia, also has an excellent anti-Vibrio activity against $V$. parahaemolyticus, $V$. vulnificus, and V. harveyi, as reported by Wahyudi et al. [14]. The antibacterial activity of Bacillus is likely to be influenced by their capability in synthesizing diketopiperazines, heat resistance compounds in size $1 \mathrm{kDa}$ [24]. Further study needs to be done to identify the anti-Vibrio compounds produced by these isolates.

D6.6 isolate was the widest spectrum of anti-Vibrio compounds producer, identified as Brevibacterium casei. This genus has also well studied as antibacterial compounds producer classified as a broad spectrum of antibacterial against both Gram-positive and Gramnegative bacteria [25]. Kiran et al. have successfully investigated the potential of marine Brevibacterium casei as Vibrio biocontrol. The study suggested that poly-hydroxy butyrate derived from that isolate was able to inhibit pathogenic bacteria on shrimp including $V$. alginolyticus and V. harfeyi [26]. Consistently, the anti-Vibrio activity of D6.6 isolate has also been confirmed by its supernatant, concentrated culture, and metabolites. The inhibitory effect of the supernatant, culture and extract indicate that the anti-Vibrio compound is likely an extracellular molecule.

The capability of supernatant, extract and culture of D6.6 isolate to inhibit Vibrio sp. is likely to be caused by activity of docosane as one of the major compounds identified. It has been reported as antibacterial by previous study [20]. The presence of this compound has been identified in the crude extract of that isolate. Wang et al. reported that docosane isolated from Metaplexis japonica has high and wide antibacterial performance against five Gram-positive and seven Gram-negative bacteria strains [20]. Other compounds were also found as dominant compounds in D6.6-derived extract, including thiophene, 2-butyl-; octadecane; silane, trimethyl-2propyne-; eicosane; 2(5H)-furanone, 5-(2-methyl-2-propenyl)-4methyl-; cyclohexane,1-(cyclohexyl methyl)-2-methyl, cis-; heptane, 1,7-dibromo-; fluoranthene; and tetracosane. Some of these compounds have been reported as biologically active compounds. They act as anticancer, antifungal, enzyme inhibitor, and cytotoxic compounds [17-21]. In conclusion, we suggest that D6.6 isolate needs to be further investigated as biocontrol candidate especially for controlling Vibriosis in shrimp caused by Vibrio sp. This is the 
first report on the anti-Vibrio activity of Brevibacterium casei isolated from Indonesian marine sponge.

\section{CONCLUSION}

Of 68 bacterial isolates, 15 isolates (22\%) showed anti-Vibrio activities in various spectra against three Vibrio species, including V. harveyi, V. parahaemolyticus, and V. vulnificus. Bacterial isolates coded as D6.6, D6.19, and P4.17 have broad spectra. Based on 16SrRNA, these isolates were closely related to Brevibacterium casei strain M Sw oHS, Bacillus altitudinis strain FJAT 47750, and Bacillus altitudinis strain PgBe190, respectively. The anti-Vibrio activity of the most potential isolate (D6.6) are also consistent as showed by its supernatants, concentrated culture, and crude extracts activities. D6.6 derived extract contains 10 major compounds which are biologically active. Based on those potential properties, these sponge-associated bacteria need to be developed as anti-Vibriosis agents.

\section{ACKNOWLEDGMENT}

This work was supported by Competence-Based Research/Basic Research from The Ministry of Research, Technology, and Higher Education of the Republic of Indonesia 2018 [Contract No. 129/SP2H/PTNBH/DRPM/2018] and 2019 [Contract No.: 3/E1/KP. PTNBH/2019] to Aris Tri Wahyudi. Therefore, the authors thank and appreciate for all the supports given to carry out this research.

\section{AUTHORS CONTRIBUTIONS}

Aris Tri Wahyudi has lead this study, took part in experimental design, integrated all experimental data, manuscript writing, and submission. Jepri Agung Priyanto has contributed in laboratory experiments, data analysis, and manuscript writing. Dian Retno Wulandari has contributed in laboratory experiments and data analysis. Rika Indri Astuti has involved in results verification, scientific discussion, and manuscript writing.

\section{CONFLICTS OF INTERESTS}

All authors declare that there are no conflict of interest.

\section{REFERENCES}

1. Chandrakala N, Priya S. Vibriosis in shrimp aquaculture a review. Int J Scientific Res Sci Eng Tech 2017;2:27-33.

2. Lee LH, Mutalib NSA, Law JWF, Wong SH, Letchumanan V. Discovery on antibiotic resistance patterns of Vibrio parahaemolyticus in selangor reveals carbapenemaseproducing Vibrio parahaemolyticus in marine and freshwater fish. Front Microbiol 2018;9:1-13.

3. Marin Lit; 2018. Available from: http://pubs.rsc.org/marinlit. [Last accessed on 10 Aug 2019].

4. Debbab A, Aly AH, Lin WH, Proksch P. Bioactive compound from marine bacteria and fungi. Microb Biotechnol 2010;3:544-63.

5. Hentschel U, Piel J, Degnan SM, Taylor MW. Genomic insights into the marine sponge microbiome. Nat Rev Microbiol 2012;10:641-5.

6. Thirumalairaj J, Shanmugasundaram T, Sivasankari K, Natarajaseenivasan K, Balagurunathan R. Isolation, screening and characterization of potent marine Streptomyces sp. PM105 against antibiotic-resistant pathogens. As J Pharm Clin Res 2015;8:439-43.

7. Murniasih T, Putra MY, Hadi TA. The antibacterial evaluation of Haliclona associated bacteria and the relating compounds derived from the host. Asian J Pharm Clin Res 2018;11:412-5.

8. Peela S, Porana S. Isolation and screening of novel streptomyces from sediment of the bay of bengal near srikakulam coast. Int J Curr Pharm Res 2017;9:40-4.

9. Prastya ME, Astuti RI, Batubara I, Wahyudi AT. Antioxidant, antiglycation and in vivo antiaging effects of metabolite extracts from marine sponge-associated bacteria. Ind J Pharm Sci 2019;81:344-53.
10. Utami AWA, Wahyudi AT, Batubara I. Toxicity, the anticancer and antioxidant activity of extract from marine bacteria associated with sponge Japsis sp. Int J Pharm Bio Sci 2014;5:917-23.

11. Safari WF, Chasanah E, Wahyudi AT. Antibacterial and anticancer activities of marine bacterial extracts and detection of genes for bioactive compound synthesis. Int J Pharm Pharm Sci 2016;8:55-9.

12. Priyanto JA, Astuti RI, Nomura J, Wahyudi AT. Bioactive compounds from sponge-associated bacteria: anticancer activity and NRPS-PKS gene expression in different carbon sources. Am J Biochem Biotechnol 2017;13:148-56.

13. Mayer AMS, Rodriguez AD, Berlinck RGS, Fusetani N. Review marine pharmacology in 2007-8: marine compounds with antibacterial, anticoagulant, antifungal, anti-inflammatory, antimalarial, antiprotozoal, anti-tuberculosis, and antiviral activities; affecting the immune and nervous system, and other miscellaneous mechanism of action. Comp Biochem Physiol 2011;153:191-22.

14. Wahyudi AT, Priyanto JA, Maharsiwi W, Astuti RA. Screening and characterization of sponge-associated bacteria producing bioactive compounds anti-Vibrio sp. Am J Biochem Biotechnol 2018;14:221-9.

15. Radjasa 0. Antibacterial activity of sponge-associated bacteria isolated from North Java Sea. J Coast Dev 2007;10:143-50.

16. Marchesi JR, Sato T, Weightman AJ, Martin TA, Fry JC, Iom SJ, et al. Design and evaluation of useful bacterium-specific PCR primers that amplify genes coding for bacterial $16 \mathrm{~S}$ rRNA. Appl Environ Microbiol 1998;64:795-9.

17. Ahmed MM, Khan MA, Rainsford KD. Synthesis of thiophene and NO-curcuminoids for anti-inflammatory and anti-cancer activities. Molecules 2013;18:1483-501.

18. Ahsan T, Chen J, Zhao X, Irfan M, Wu Y. Extraction and identification of bioactive compounds (eicosane and dibutyl phthalate) produced by Streptomyces strain KX852460 for the biological control of Rhizoctonia solani AG-3 strain KX852461 to control target spot disease in tobacco leaf. AMB Express 2017;7:1-9.

19. Willett KL, Wassenberg D, Lienesch L, Reichert W, Giulio RTD. In vivo and in vitro inhibition of CYP1A-dependent activity in Fundulus heteroclitus by the polynuclear aromatic hydrocarbon fluoranthene. Toxicol Appl Pharmacol 2001; 177:264-71.

20. Wang DC, Sun SH, Shi LN, Qiu DR, Li X, Wei DS, et al. Chemical composition, the antibacterial and antioxidant activity of the essential oils of Metaplexis japonica and their antibacterial components. Int J Food Sci Tech 2014;50:449-57.

21. Uddin SJ, Grice D, Tiralongo E. Evaluation of cytotoxic activity of patriscabratine, tetracosane and various flavonoids isolated from the Bangladeshi medicinal plant Acrostichum aureus. Pharm Bio 2012;50:1276-80.

22. Gao X, Liu Y, Miao L, Li E, Hou T, Liu Z. Mechanism of anti-Vibrio activity of marine probiotic strain Bacillus pumilus $\mathrm{H} 2$, and characterization of the active substance. AMB Express 2017;7:1-10.

23. Abubakar H, Wahyudi AT, Yuhana M. Skrining bakteri yang berasosiasi dengan spons Japsis sp. sebagai penghasil senyawa antimikroba. Il Kelautan 2011;16:35-40.

24. Leyton Y, Borquez J, Darias J, Cueto M, Diaz Marrero AR, Riquelme C. Diketopiperazines produces by an Bacillus species inhibits Vibrio parahaemolyticus. J Aquat Res Dev 2012;3:1-5.

25. Boucabeille C, Mengin Lecreulx D, Henkes G, Simonet J, Heijenoort JV. Antibacterial and hemolytic activities of linenscin OC2, a hydrophobic substance produced by Brevibacterium linens OC2. FEMS Microbiol Lett 1997;153: 295-301.

26. Kiran GS, Lipton AN, Priyadharsini S, Anitha K, Suarez LEC, Arasu MV, et al. Antiadhesive activity of poly-hydroxy butyrate biopolymer from a marine Brevibacterium casei MSI04 against shrimp pathogenic Vibrios. Microbiol Cell Fact 2014;13:1-12. 